\title{
Study of Waste Management Flats Case Study: Simple Rent Flats (Rusunawa) Kayu Putih
}

\author{
Dani Fadila1, N. M. Siahaan", D. Lindarto ${ }^{1}$ \\ ${ }^{1}$ Architecture Department, Faculty of Engineering, Universitas Sumatera Utara, Medan, \\ North Sumatra, Indonesia \\ Corresponding Author: Dani Fadila
}

\begin{abstract}
The absence of the implementation of policies regarding waste management for flats for residents and managers is one of the causes of the waste management of flats not running in accordance with the applicable laws and regulations. While the implementation of vertical housing such as flats will continue to be developed by the government in an effort to increase land use in urban areas.

This research aims to examine the conditions of waste management in the area of the Kayu Putih Flats, Medan. The research was carried out with a descriptive qualitative approach, namely by measuring waste generation and observing the pattern of waste management applied by the residents and managers of the flats. In this way, the point of the problem of waste management will be known.
\end{abstract}

Keywords: Waste Management, Flats, Knowledge.

\section{INTRODUCTION}

The urbanization rate of Medan City in the last 10 years can be seen from its population growth. In 2020, the population of Medan City reached 2,435,252 inhabitants. Compared to the total population in 2019, there was an increase in the population of 155,358 people $(6.81 \%)$. Population growth that occurs is accompanied by an increase in the amount of waste generated.

Waste is solid waste material from household activities, markets, offices, inns, hotels, restaurants, industries, building material debris and scrap metal used for motor vehicles. Waste is a by-product of human activities that have been used (Sucipto, 2012). Waste is one of the problems in big cities that is always discussed both in developed and developing countries. In Indonesia, the problem of waste is no longer a new problem.

Reporting from the Ministry of Environment and Forestry, the achievement of waste generation in 2019 reached 31.3 million tons/year, with the percentage of unmanaged waste at $32.36 \%$ or 11.9 million tons/year. Urban areas also contribute to waste seen from the number of daily activities that take place. To overcome this, it is necessary to have an appropriate waste management system.

According to Rahmayanti (2016), the system must be able to serve the entire population and improve public health standards, which cannot be separated from the active role of the community and the private sector. Community participation is the most important aspect in an integrated waste management system to deal with increasingly complex waste problems. The existence of the right mechanism not only has a positive impact on the environment, but can also provide benefits from an economic point of view, where initially useless waste is processed so as to produce a good selling value.

However, the rate of population growth that is not matched by the improvement of the quality of facilities and infrastructure related to waste management allows various problems to arise in the long 
term, especially for the city of Medan which is the 3rd largest city. According to the Sanitation Department in 2019 based on the results of data collection conducted by each resident, Medan City produces $0.7 \mathrm{~kg}$ of waste per day and $56 \%$ of it from household waste. When multiplied by the total population of Medan City, which currently reaches around 2.9 million, the residents produce around 2000 tons of waste every day. Most of the waste is not managed properly.

For rental flats, the income of the middle and lower economic community is also the cause of the low behavior of protecting the environment which has an impact on garbage scattered both on roads and in rivers (Rahmayanti, 2016). Kayu Putih flat is one of the simple flats located in a sub-commercial area of Medan city growth and is part of the Belawan SWK and is directed as a medium and high density housing zone.

The availability of infrastructure and utilities is generally quite complete, especially for waste facilities, there is 1 TPS which is located adjacent to the Kayu Putih flat. However, this does not necessarily make the waste processing in the flats under control. There is still a lot of waste accumulation around the TPS of the Kayu Putih flat. The regulations and strategies that have been designed today must be accompanied by concrete actions from the government and the community.

The government needs to start introducing appropriate and effective waste management processes to the community and must implement and supervise its implementation in order to reduce the volume of waste that will continue to grow every day. To be able to answer this problem, it is necessary to conduct a study of urban waste management in simple rental flats for Kayu Putih rent. In order to find out the root of the problem based on the perception of the residents and find solutions in improving the performance of waste management infrastructure suggestions in flats. To create a residential environment that is healthy and prosperous as well.

\section{LITERATURE REVIEW}

Increasing population growth rates and the lack of land availability encourage vertical residential development planning, especially for urban communities (Sabarudin, 2018). This increase also affects Low-Income Communities (MBR) due to high demand for housing needs, which also increases urban land prices.

According to Utami, et al. (2016), in an effort to ensure the need for decent and affordable housing, it is planned to build flats for MBR with a rental system for a certain period of time, or commonly referred to as simple rental flats (rusunawa). Rusunawa as affordable settlements are an indication of achieving a balance between household income and housing costs (Kubey, 2018).

The facilities that must be fulfilled in the construction of flats as stipulated in SNI 03-7013-2004 are:
a. commercial facilities;
b. educational facilities;
c. medical facility;
d. worship facilities;
e. government facilities;
f. outdoor; and
g. connection between facilities

The availability of these facilities is inseparable from the management and maintenance efforts that involve both managers and residents of the flats. Then waste management has a very basic goal which includes improving environmental and community health, protecting natural resources (water), protecting socioeconomic facilities and supporting strategic sectors (Rahardyan and Widagdo, 2005).

The increasing generation of waste is a problem that must be handled as early as possible so as not to cause prolonged problems, such as decreasing environmental aesthetics, increasing environmental pollution to the emergence of diarrheal diseases, cholera, typhus, DHF (Paauthor, 2017; and Mahyudin, 2017). Basically, the 
increase in pollution that occurs is related to the improper implementation of waste processing (Giusti, 2009). It can be seen from the closest environment, namely residential areas, as recorded by the Ministry of Environment and Forestry (KLHK) that the largest source of waste comes from households with a percentage of $37.4 \%$.

In the Medan Mayor Regulation Number 26 of 2019, the government plans a strategy related to the management of household waste and waste similar to household waste, one of which is strengthening community involvement through communication, information and education (KIE) with the following programs:

a. Increased reduction in household waste and similar household waste through formal and informal IEC;

b. Development of activities for recycling and re-utilizing household waste and similar household waste at household scale and community-based settlement scale;

c. Development of activities for recycling and re-utilizing household waste and similar household waste at household scale and area-based settlement scale;

d. Education includes extracurricular education, running libraries, training for PKK, subject curricula, and educational parks.

Not only that, the Medan City Government has also developed a strategy for the establishment of an information system regarding the operational data of the Waste Bank and 3R TPS which is integrated with the Environmental Information System (SILH) in sub-districts and kelurahan. The pattern of waste management in Indonesia is still applying the old pattern, namely gathering-transport-disposal. In fact, it should have started to implement the $3 \mathrm{R}$ (reduce, reuse, and recycle) to the fullest. Regulation of the Minister of Public Works of the Republic of Indonesia Number 03/PRT/M/2013 has also regulated waste management, including:
a. sorting;
b. collection;
c. transportation;
d. processing; and
e. waste final processing
Prior to final processing or waste destruction at the TPA, usually the waste collected at the trans depot is sorted using the $3 \mathrm{R}$ (reduce, reuse, and recycle) system to minimize the volume of waste that enters the TPA (Sahil, et al., 2016).

\section{METHODS}

The research of waste management in the Kayu Putih simple rental flats (rusunawa) was carried out to find problems in efforts to manage waste in the area that caused the accumulation of garbage, and then provide solutions that could be applied by both residents and managers. To be able to identify these problems, this research uses descriptive qualitative methods that describe the condition of the object of research in the field and its characteristics systematically.

\section{RESULT AND DISCUSSION}

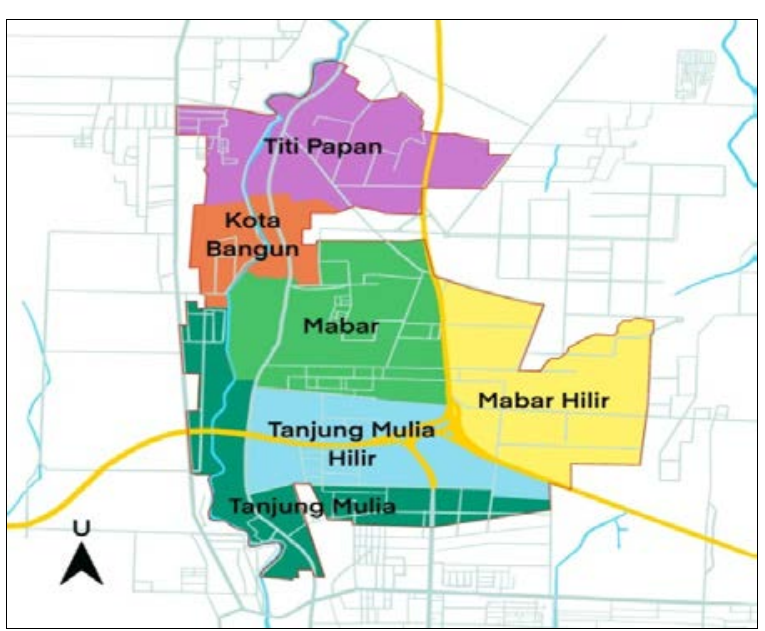

Figure 1: Regional Map of Medan Deli Sub-District

Simple rental flats (rusunawa) Kayu Putih located on Jl. Kayu Putih, Tj. MuliaHilir, Medan Deli District, Medan City, North Sumatra. Geographically, it is at coordinates 3.65404, 98.66633. The village area of $\mathrm{Tj}$. MuliaHilir has an area of 2.31 $\mathrm{km} 2$. Kayu Putih flat is one of the simple flats located in a sub-commercial area of Medan city growth and is part of the 
Belawan SWK and is directed as a medium and high density housing zone.

Simple rental flats (rusunawa) are a government program in providing vertical housing for the surrounding community or migrant workers who do not yet own a private house due to insufficient economic conditions. Until now, in Medan City there are 4 Rusunawa that have been built, one of which is Rusunawa Kayu Putih.

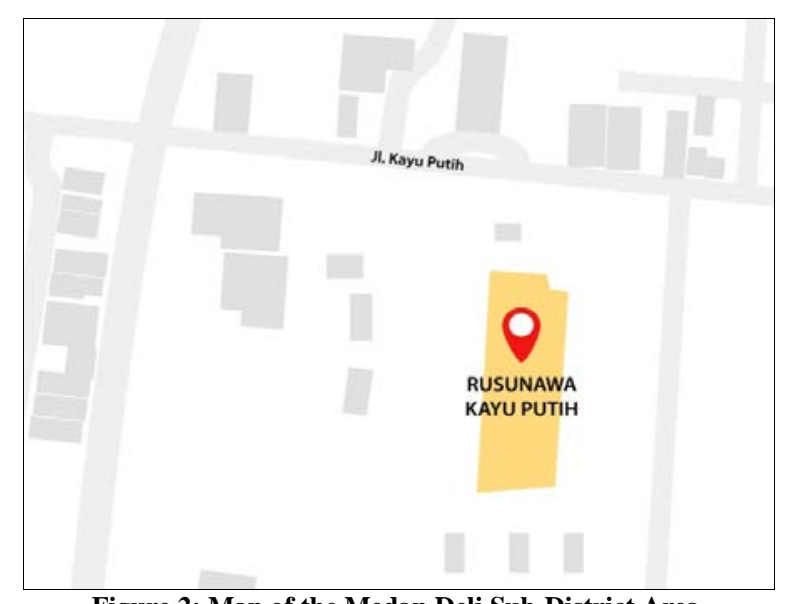

Figure 2: Map of the Medan Deli Sub-District Area

The pattern of waste collection applied in Rusunawa Kayu Putih is an indirect communal pattern. Where the residents will use the garbage shaft provided in the Rusunawa building, then the waste will be transported by the cleaning staff using a waste cart to the TPS and followed by a waste truck to the TPA Terjun, Marelan.

According to Sudrajat (2006) the estimated volume of waste for one family is $0.014 \mathrm{~m} 3$ or 2.8 liters per person. So, with the number of families per block in Rusunawa Kayu Putih is 83 families, the estimated waste generation per block is 5.93 $\mathrm{m} 3$, which means for a total generation of 4 filled blocks are $23,7 \mathrm{~m}^{3}$.

From the results of observations, the transportation of waste on the Rusunawa Kayu Putih shaft is carried out every 2-3 days using 1 unit of waste tricycles with a capacity of $2 \mathrm{~m} 3$ for one block with 4 cycles. This causes there is still waste that is not transported from the shaft and causes accumulation in the waste collection tank.
Table 1: Estimated Waste Generation Per Block

\begin{tabular}{|c|c|c|}
\hline Explanation & Volume & Satuan \\
\hline Wastge Generation & 11.86 & $\mathrm{~m}^{3}$ \\
\hline Transport by Pedicab & 8 & $\mathrm{~m}^{3}$ \\
\hline Leftover WasteGeneration & 3.86 & $\mathrm{~m}^{3}$ \\
\hline
\end{tabular}

The attitude of the residents of the flats towards the waste management have been carried out based on the results of the questionnaire is as follows:

a. In general, the residents of Rusunawa Kayu Putih understand that the waste produced can still be sorted and can have economic value if it is directed and managed properly (70\%).

b. Rusunawa residents understand the basic differences between organic waste and inorganic waste $(68.75 \%)$, but further socialization and direction are still needed so that the residents of the flats can directly implement good management patterns.

c. The residents of the flats have not implemented the 3R system, so the waste generated will be immediately disposed of without any sorting process, this is also encouraged by the Rusunawa managers who do not implement the $3 \mathrm{R}$ system in the disposal process.

d. Most of the residents of the flats still don't understand the 3R concept (85\%), in other words, there is a need for counseling or socialization so that it can direct residents to take part in reducing the volume of waste generated.

e. The occupants of the flats agree that the cleanliness of the apartment's environment is not only the responsibility of the manager, but also the occupants, this can be seen from the condition of the clean apartment building (figure 4.18).

$\mathrm{f}$. Weak governance is considered to be the cause of waste management that is not optimal; the lack of strict regulations regarding waste sorting in the long term will cause waste to accumulate.

g. There are no strict sanctions to follow up on people who throw garbage in the area outside the Rusunawa building so that there is still trash scattered about. 


\section{Waste Sorting}

Within the Rusunawa Kayu Putih area, each family is responsible for each household's waste. The residents have their own garbage containers located in each unit in the form of plastic trash cans, then the waste will be directly disposed of to the garbage shaft located on each floor, without going through the 3R (reduce, reuse, and recycle) sorting process which is then transported to the TPS.

The management of Rusunawa Kayu Putih also does not provide a separate container for grouping waste. This of course contradicts SNI 19-2454-2002 regarding waste sorting. In the end, the segregation of the collected waste will be carried out by the informal sector such as scavengers who sort the waste for later resale.

\section{Waste Collection}

Each block of Rusunawa Kayu Putih is provided with a waste collection area in the form of vertical trash shafts located on the right and left sides of the building with dimensions of $2 \mathrm{mx} 1.5 \mathrm{~m}$, with the furthest distance of $30 \mathrm{~m}$ for residents to reach the shaft, as shown in yellow on the plan of the Rusunawa building in Figure 3 and Figure 4. The shaft and waste collection in Rusunawa Kayu Putih accordance with the standards stated in the Minister of Public Works Regulation Number 60 of 1992.
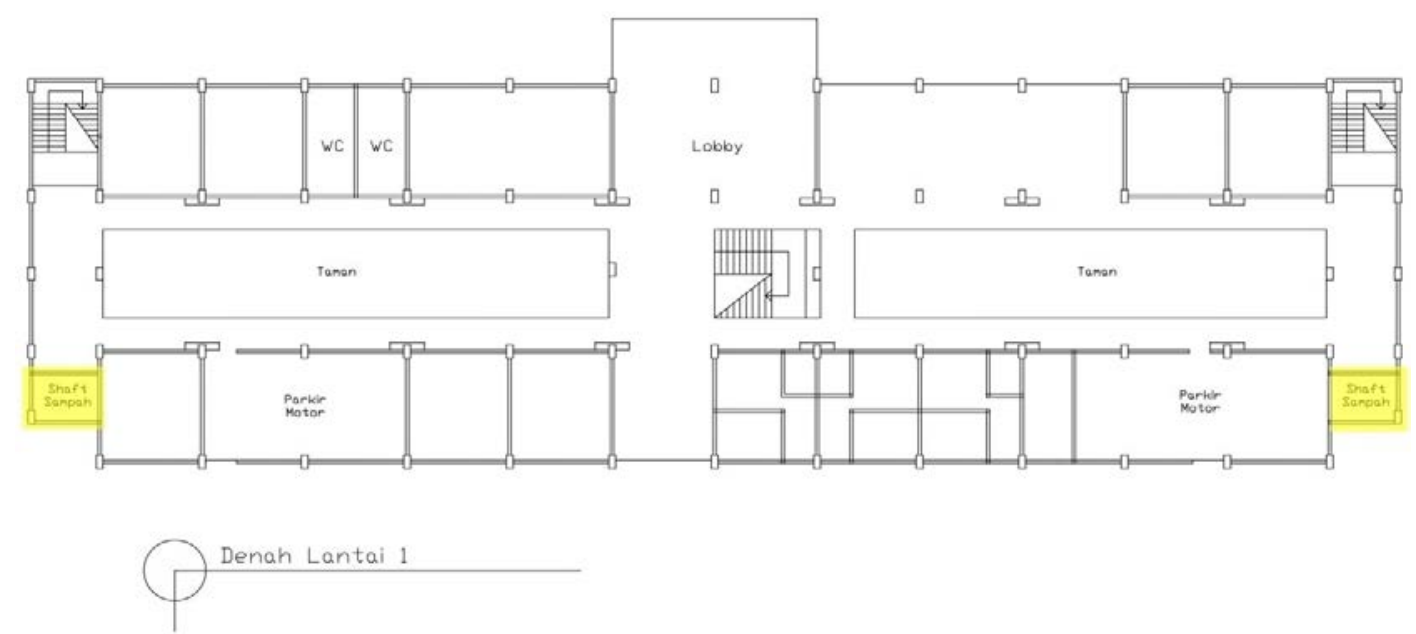

Figure 3: Flat Plan 1 Rusunawa Kayu Putih
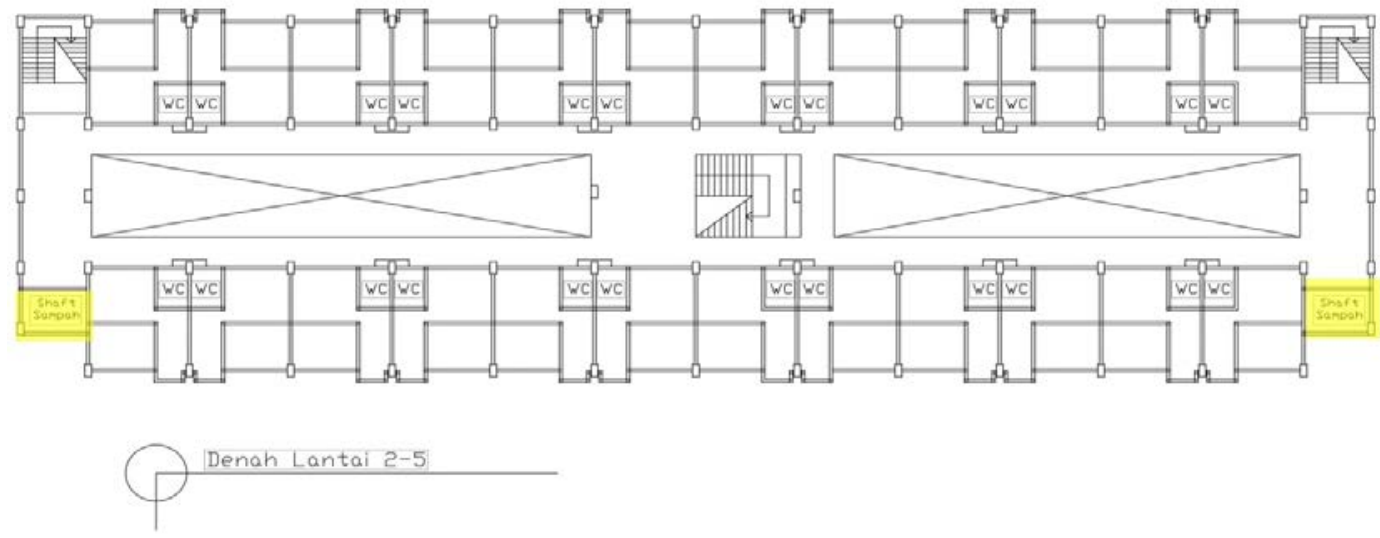

Figure 4: Flat Plan 2-5 Rusunawa Kayu Putih

The disposal shaft and the garbage collection tank at Rusunawa Kayu Putih are made of permanent materials, namely brick walls with metal covers, and are sufficient to accommodate 2 days of garbage.
However, there are several shaft covers that have been damaged. This of course will lead to scattered waste if not repaired. The waste generated by the residents of the Kayu PutihRusunawa is quite diverse, ranging 
from plastic, paper, to organic waste, in the form of food waste.

\section{Waste Pick-up}

Waste transportation in Rusunawa Kayu Putih is carried out every 2-3 days, every 7 or 8 in the morning using a garbage cart or tricycle with a capacity of $2 \mathrm{~m} 3$ directly without any waste sorting process. Then, the collected waste is immediately transported to the TPS located on Yos Sudarso Street, Medan, about $850 \mathrm{~m}$ away from Rusunawa Kayu Putih. In other words, in this process it has met the standards set out in the Minister of Public Works Regulation No. 60/PRT/1992.

Furthermore, the waste will be transported to the Marelan Falls TPA by using a garbage truck with a capacity of 8 $\mathrm{m}^{3}$. Most of the waste transported is household waste and similar types of household waste and road sweeping waste. City waste trucks operate 3 times a week.

Considering the volume of incoming waste, this operational frequency is not effective. Overall, the conditions inside Kayu PutihRusunawa are quite clean, and there is no visible waste that has piled up or scattered. However, outside the Rusunawa Kayu Putih area, there are several points of waste accumulation on the roadside that are not transported and can be quite disturbing (figure 4). This pile of waste comes from people outside the residents of the flats.

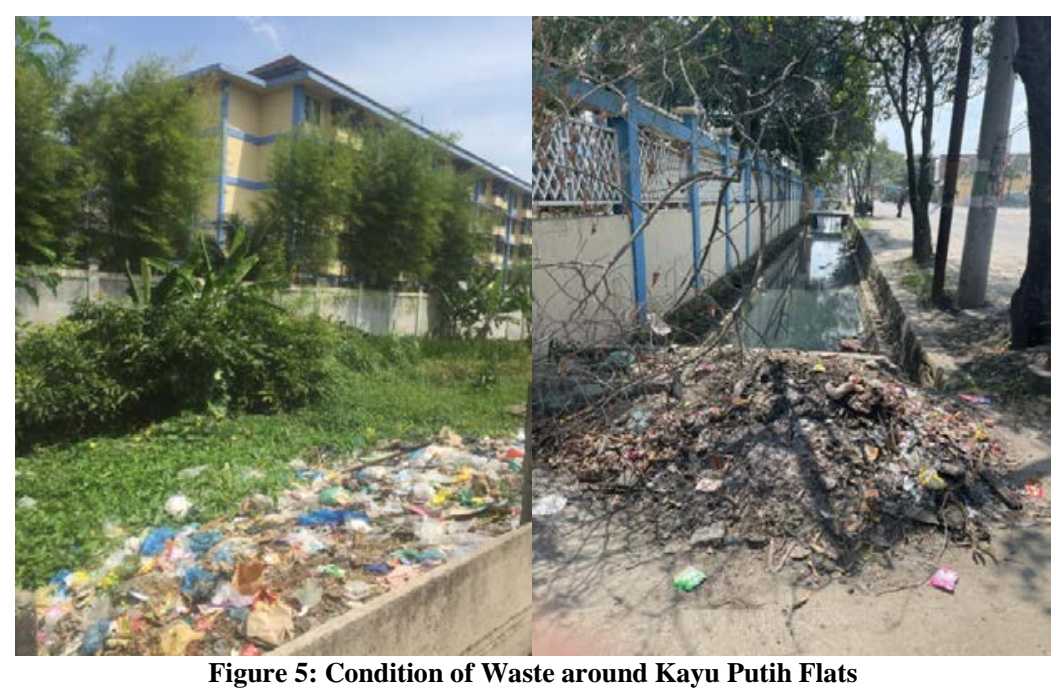

\section{Waste Management}

The waste of Rusunawa Kayu Putih Medan is generally household waste. The absence of a waste sorting or grouping process on this scale, as previously described, causes the waste management process to not be implemented. This is very unfortunate because the waste produced has the potential to be processed into recycled goods and the formation of useful compost as described in SNI 3242-2008.

Rusunawa Kayu Putih residents belonging to low-income communities (MBR) have the potential to play an active role in reducing waste because of the tendency to reuse items that are still functioning, as explained by Murad and
Siwar (2015). However, the limited facilities for the sorting process in the flats cause the process of processing the segregated waste to not be carried out.

This has been emphasized in research conducted by Refsgaard and Magnussen (2009) and Keramitsoglou and Tsagarakis (2013) namely, the sorting process to the implementation of recycling among the community is influenced by the accessibility of waste recycling facilities as well as knowledge about sorting and recycling. The absence of waste grouping carried out in the previous stage, most of the waste that enters the TPA has been mixed into one so that it hampers the waste processing process. 
Based on the data obtained from the person in charge of the MarelanTPA Terjun, the waste processing process in the form of composting cannot be carried out because the condition of the equipment is damaged. This of course causes the accumulation of waste to continue to occur. In other words, the waste processing process at TPA Terjun does not run in accordance with PP No. 81 of 2012 and SNI 19-2454-2002.

\section{Waste Processing}

Final processing of waste is carried out at the Marelan TPA Terjun which operates from 04.00 WIB. There is quite a lot of waste entering the Marelan TPA Terjunbecause there is only 1 TPA that handles Medan City waste, in other words, there are many queues of garbage trucks that will enter to weigh the volume of waste. The location of the Marelan Falls TPA is far enough from the settlements so that it can anticipate the risks posed.

In the final processing, it can be seen that the mountain of waste is burned at several points, which is far from being environmentally friendly due to the production of methane gas produced. Then, the waste will be filled with soil so that it can be filled with the next incoming garbage. This condition clearly contradicts PP No. 81 of 2021 and SNI 3242-2008.

\section{CONCLUSION}

The awareness of residents in maintaining the cleanliness of the apartment environment needs to be supported by a more mature policy to optimize efforts to reduce the volume of waste generated. From the studies that have been carried out, several conclusions can be drawn, namely the waste management of Rusunawa Kayu Putih using an indirect communal pattern, in which residents dispose of waste through trash shafts located on each floor, to the trash bin.

The waste will be transported using tricycles or garbage carts to the TPS every 2-3 days per 2 blocks, and forwarded to the Marelan Falls TPA using a garbage truck.
The waste infrastructure in Rusunawa Kayu Putih is still not optimal, one of which is that neither the manager nor the occupants apply the 3R system in its management, so that the waste that reaches the landfill has been mixed into one.

In addition, garbage problems also arise outside the Rusunawa building, in other words, the people around the Kayu Putih Rusunawa still tend to throw garbage on the side of the road, causing piles of garbage which if left unchecked will continue to build up and disrupt public health.

Therefore, there is a need for more mature policies related to the implementation of waste management using the 3R system or providing composting training to reduce the volume of waste generated by residents. Residents of the flats should be given socialization and counseling related to the long-term impact of the implementation of the system supported by the provision of related facilities.

The Medan City Sanitation Service also needs to review the scattered TPS points so that they are more easily accessible to the public so that the habit of disposing of waste in places that should not be improved gradually. The conditions of TPS and TPA that are still functioning well are also better maintained in order to extend the operational period considering that the volume of incoming waste will continue to increase every year.

\section{Acknowledgement: None}

\section{Conflict of Interest: None}

\section{Source of Funding: None}

\section{REFERENCES}

1. Badan Standarisasi Nasional. (2002). Standar Nasional Indonesia: Tata Cara Teknik Operasional Pengelolaan Sampah Perkotaan. SNI 19-2454-2002.

2. Badan Standarisasi Nasional. (2008). Standar Nasional Indonesia: Pengelolaan Sampah di Permukiman. SNI 3242-2008. 
3. Kubey, K. (Ed.). (2018). Housing as Intervention: Architecture towards social equity. John Wiley \& Sons.

4. Kementerian LingkunganHidup dan Kehutanan. 2019. SistemInformasi PengelolaanSampah Nasional. Jakarta: Kementerian LingkunganHidup dan Kehutanan.

5. Keramitsoglou, K. M., \&Tsagarakis, K. P. (2013). Public participation in designing a recycling scheme towards maximum public acceptance. Resources, Conservation and Recycling, 70, 55-67.

6. Mahyudin, R. P. (2017). Kajian Permasalahan Pengelolaan Sampah dan Dampak Lingkungan di TPA (Tempat Pemrosesan Akhir). Jukung (Jurnal Teknik Lingkungan), 3(1).

7. Murad, W., \&Siwar, C. (2007). Waste management and recycling practices of the urban poor: a case study in Kuala Lumpur city, Malaysia. Waste management \& research, 25(1), 3-13.

8. Pawenang, E. T. (2017). Kondisi Sanitasi dan Kepadatan Lalat Kantin Sekolah Dasar Wilayah Kerja Puskesmas Kedungmundu. JHE (Journal of Health Education), 2(1), 101-106.

9. Peraturan Menteri PekerjaanUmum. (1992). Nomor 60/PRT/1992 TentangPersyaratan Teknis Pembangunan RumahSusun, Jakarta.

10. PeraturanPemerintah. (2012). Nomor 81 TentangPengelolaanSampahRumahTangga dan SampahSejenisSampahRumahTangga. Jakarta.

11. Rahardyan, B., \& Widagdo, A. S. (2005). Peningkatan pengelolaan persampahan perkotaan melalui pengembangan daur ulang. Materi Lokakarya, 2.

12. Rahmayanti, H. (2016). KonsepPemahaman dan TeknologiPengelolaanSampah di RumahSusunSewa. ETHOS: JurnalPenelitian dan Pengabdiankepada Masyarakat, 35-40.

13. Refsgaard, K., \& Magnussen, K. (2009). Household behaviour and attitudes with respect to recycling food waste-experiences from focus groups. Journal of Environmental management, 90(2), 760771.

14. Sabaruddin, A. (2018, February). Hakekat Hunian Vertikal di Perkotaan. In Prosiding Seminar Kota Layak Huni/Livable Space.

15. Sahil, J., Al Muhdar, M. H. I., Rohman, F., \& Syamsuri, I. (2016). Sistem pengelolaan dan upaya penanggulangan sampah di Kelurahan Dufa-Dufa Kota Ternate. BIOeduKASI, 4(2).

16. Sucipto, C. D. (2012). Teknologipengolahandaurulangsampah. Yog yakarta: Gosyen Publishing.

17. Sudrajat, H. R. (2006). Mengelolasampahkota. NiagaSwadaya.

18. Utami, M. N., Setiadi, A. K., Sanjaya, B., Nurzakiah, D., \& Pamungkas, G. A. (2016). Kelengkapan Fasilitas Di Rumah Susun Sederhana Sewa Cingised Ditinjau dari SNI 03-7013-2004. Reka Karsa, 4(4).

How to cite this article: Dani Fadila, N. M. Siahaan, D. Lindarto. Study of waste management flats Case study: simple rent flats (Rusunawa) Kayu Putih. International Journal of Research and Review. 2021; 8(12): 241-248. DOI: https://doi.org/10.52403/ijrr.20211230 